\title{
Where are the Great Women? A feminist analysis of Australian political biographies
}

\author{
BLAIR WILLIAMS
}

\section{Introduction}

As women have become more visible in the Australian political sphere, the volume of writing about their lives, careers and experiences has also increased. This has brought to light certain challenges and shortcomings, as well as enduring discursive biases in the existing literature. Political history, for example, and especially political biography, has generally 'privileged the political activities of men and masculine political institutions', telling the stories of so-called Great Men while excluding those who do not traditionally belong to this cohort. ${ }^{1}$ Any attempt to summarise the current state of biographies written on Australian political women and to assess the extent to which these can be improved must therefore address several overlapping lines of inquiry, the four most fundamental of which have been chosen for discussion in this article. First, I will provide an overview of the institutional and discursive masculine biases of political biographies in general. Second, I will outline the state of biographies written on women politicians, noting the lack of such texts and an increasing turn towards autobiography. Third, I compare two recent biographies on women politicians-Anna Broinowski's Please Explain (2017) and Margaret Simons's Penny Wong (2019) — to demonstrate how a tendency towards excessive personalisation can become problematic. Lastly, by exploring feminist approaches to political biography, I provide a working definition of feminist political biography and propose a list of 'dos and don'ts' for those political biographers who seek to develop a more inclusive model.

I acknowledge that my expertise does not lie in the realm of political biographies or history. Rather, I am a feminist political scientist who researches the gendered media coverage of women in politics, examining the language that is used. Due to the interdisciplinary nature of my research, I provide a well-rounded and contextualised perspective on women, language and politics that I can apply to public biographical writing of women politicians, resulting in a more holistic and interdisciplinary picture.

1 Kate Murphy, 'Feminism and Political History', Australian Journal of Politics and History 56, no. 1 (2010): 21, doi.org/10.1111/j.1467-8497.2010.01539.x. 


\section{Political biographies: Myth-building Great Men}

The writing of traditional biographies has generally been defined as the creation of a coherent narrative around significant events in the life story of a chosen subject. Political biography goes beyond this to weave a narrative that not only recreates life, but says 'something about the conduct of politics'. ${ }^{2}$ Through the analysis of letters, diaries, Hansard records and interviews, political biographers can provide nuanced insights into the lives of politicians through which readers can gain a greater understanding of their performances, positions and decisions and their successes and failures. Emphasising the human element, political biographers seek to add life, colour and depth to historical events, 'in the way human beings actually experience them'. ${ }^{3}$ They can further provide a unique perspective on power itself, exposing how it is afforded, exercised and shared. ${ }^{4}$ Discursively, political biographers can also create and shape the legacies of the politicians about whom they chose to write, thereby signifying who is 'worthy' of being written about and who is overlooked. This can, in turn, shed light on the conduct of civic life in general-who belongs, who is excluded and what are the accepted norms by which we all are expected to abide as citizens.

Most currently available Australian political biographies have been written about men. Despite this clear bias, however, the authors of these biographies tend to largely ignore the gender of their subjects and, as Kate Murphy argues, 'the masculinity of great leaders and politicians is ... thus "invisible" in the broader analysis of character'. While they emphasise male politicians' private lives, character and disposition, attaching them to their public persona, they do so in a way that avoids a gendered analysis and, instead, positions the latter as manifestations of an assumed universal subject. Masculinity is thereby portrayed as the unseen norm while gender is an attribute only ever identified with women. ${ }^{6}$ This is hardly surprising, considering the relative dearth of women in politics for most of the twentieth century, yet it reinforces the public/private gender binary and endorses the idea that parliament is a masculine domain.?

\footnotetext{
2 James Walter, 'Political Biography', in The Australian Study of Politics, ed. R. Rhodes (London: Palgrave Macmillan, 2009), 97, doi.org/10.1057/9780230296848_7.

3 Ben Pimlott, 'Is Contemporary Biography History?', Political Quarterly 70, no. 1 (1999): 34, doi.org/10.1111/ 1467-923X.00202.

4 Tracey Arklay, 'Political Biography: Its Contribution to Political Science', in Australian Political Lives: Chronicling Political Careers and Administrative History, ed. Tracey Arklay, John Nethercote and John Wanna (Canberra: ANU E Press, 2006), 13, doi.org/10.22459/APL.10.2006.02.

5 Murphy, 'Feminism and Political History', 36.

6 Murphy, 'Feminism and Political History', 36.

7 Mary Crawford and Barbara Pini, 'The Australian Parliament: A Gendered Organisation', Parliamentary Affairs 64, no. 1 (2010): 82-105, doi.org/10.1093/pa/gsq047.
} 
This type of political biography also contributes to the endurance of a popular vision of politics as a succession of 'Great Men', a term coined by Thomas Carlyle in a series of lectures published in 1841. For Carlyle, 'the history of the world is but the biography of great men': ${ }^{2}$

They were the leaders of men, these great ones; the modellers, patterns, and in a wide sense creators, of whatsoever the general mass of men contrived to do or to attain; all things that we see standing accomplished in the world are properly the outer material result, the practical realization and embodiment, of Thoughts that dwelt in the Great Men sent into the world: the soul of the whole world's history, it may justly be considered, were the history of these.

Unsurprisingly, this theory completely erased the influence of women from the historical record, though it also excluded most of the male population as well, as the distinction of being a Great Man was solely reserved in Carlyle's estimation for the rich and powerful. ${ }^{10}$ Though the idea of the Great Man sounds anachronistic to the contemporary ear, this narrative has nevertheless endured in popular and even some scholarly accounts of historical change, and especially in the still remarkably male-dominated sphere of politics, where the cult of the strong leader retains a palpable influence. This is visible not only in extremist movements but also in democratic nation states, gaining even greater traction in recent years with the global rise of right-wing populism. ${ }^{11}$ Both historical progress and the privilege of political leadership, in this discursive model, are 'irredeemably masculine' and Eurocentric, reserved for a certain kind of rich white men. ${ }^{12}$

This tendency begs the question: can there be Great Women? It appears that the whole discourse is resistant to the existence of such individuals. Lucy Riall's research examines the Great Man narrative, tracing its influence from Carlyle to its persistent use in the British Dictionary of National Biography (DNB) from the 1880s to the 1970s. ${ }^{13}$ While not explicitly endorsing Carlyle's model of history, the authors of the DNB were long guided by the principle of the 'heroic model of biography' linking biography and nation, the latter restricted in extent to those who were 'noteworthy inhabitants of the British Islands and the Colonies'. ${ }^{14}$ Additionally, their overwhelming preoccupation with the careers of 'great' public men, largely the political elite, meant that women were almost entirely excluded from the pages

8 Thomas Carlyle, On Heroes, Hero-Worship, and the Heroic in History (London: James Fraser, 1841), 47.

9 Carlyle, On Heroes, 1.

10 Nico Mouton, 'A Literary Perspective on the Limits of Leadership: Tolstoy's Critique of the Great Man Theory', Leadership 15, no. 1 (2019): 81, doi.org/10.1177/1742715017738823.

11 Mouton, 'A Literary Perspective on the Limits of Leadership', 82; Archie Brown, 'Questioning the Mythology of the Strong Leader', Leadership 11, no. 3 (2015): 374-79, doi.org/10.1177/1742715015590066.

12 Keith Grint, 'A History of Leadership', in The Sage Handbook of Leadership, ed. Alan Bryman, David Collinson, Keith Grint, Brad Jackson and Mary Uhl-Bien (London: Sage, 2011), 8.

13 Lucy Riall, 'The Shallow End of History? The Substance and Future of Political Biography', The Journal of Interdisciplinary History 40, no. 3 (2010): 375-97, doi.org/10.1162/jinh.2010.40.3.375.

14 Riall, 'The Shallow End of History?', 377. 
of the DNB for many decades. As Riall observes, out of the 63 volumes published by the DNB prior to 1901, women only made up 4 per cent of the 'noteworthy inhabitants' and 7 per cent of contributors. ${ }^{15}$ This seems to suggest that, aside from a few exceptions, women cannot aspire to be considered Great in the manner championed by Carlyle and the authors of the DNB, for whom this was a label solely reserved for men. As Linda Nochlin famously argued in her 1971 analysis of the institutional obstacles preventing women from succeeding in the Arts:

But in actuality, as we all know, things as they are and as they have been, in the arts as in a hundred other areas, are stultifying, oppressive and discouraging to all those, women among them, who did not have the good fortune to be born white, preferably middle class and, above all, male. The fault, dear brothers, lies not in our stars, our hormones, our menstrual cycles or our empty internal spaces, but in our institutions and our education. ${ }^{16}$

Historically, women have not had the opportunity to become Great Politicians worthy of a series of biographical texts. As these texts continue to contribute to our collective understanding of those personal and political qualities that comprise 'Greatness', and as they are mostly written about men, we therefore habitually connect these qualities with masculinity and maleness. Though biographers have largely moved on from this overarching discourse in recent decades, the field of political biography remains a significantly masculine domain, continuing to imply that women's lives and women's stories are not worth recording.

\section{Feminist political biographies}

Traditional political biographies have therefore largely focused on men even while completely ignoring the issue of gender. As Murphy puts it, 'political historians equated politics with parliaments and (mainly male) parliamentarians, and thus overlooked political activities that fell outside these parameters'. ${ }^{17}$ While history as a discipline has grappled with gender issues since the 1970s, political history in particular, like its 'male-dominated cousin' political science, has been especially resistant to questions about women and gender or the value of feminist analysis. ${ }^{18}$ Feminist scholars across the disciplines have challenged this perspective since the rise of the feminist movement in the social sciences and humanities in the 1970s. Through their scholarship, they have aimed to make gender visible-from highlighting 'women's history' to applying a gendered analysis to the actions of men-thereby demonstrating the significance of gender in historical narrative,

15 Riall, 'The Shallow End of History?', 378.

16 Linda Nochlin, 'Why Have There Been No Great Women Artists?', in Linda Nochlin, Women, Art, and Power and Other Essays, 1st ed. (New York: Routledge, 1988), 145-78, doi.org/10.4324/9780429502996-7.

17 Murphy, 'Feminism and Political History', 21.

18 Murphy, 'Feminism and Political History', 23. 
discourse and knowledge. ${ }^{19}$ Feminist scholars have played a particularly substantial role in widening the scope of history and have contributed innovative conceptual approaches to this discipline, demonstrating that women's lives are 'no less historically important than men's' ${ }^{20}$

Yet feminist scholars have remained apprehensive about the value of biography, as a genre that has historically emphasised, even constituted, the public 'autonomous man'. ${ }^{21}$ An enduring tendency to focus on public men's private lives as a counterpoint to or motivating influence on their public successes and failures has been an especially thorny source of tension due to the historical links tying women to the private or domestic sphere. Focusing on women's private lives to the same extent runs the risk of confirming 'their status as the second sex', whereby they are trivialised and either seen as 'ahistorical exceptions to the rule or as exemplary of their 'species'" ${ }^{22}$ Bearing this in mind, we might ask: how can we reformulate biographical writing to adhere to a more feminist practice? What is it that interests us about the lives of women? Is it their achievements, life stories or the social adversities they have had to endure? In response to questions such as these, feminist biographers have largely sought to understand how their subjects experienced, rather than constituted, the world around them and, departing from a hyper-individualistic focus, they have emphasised the shared experiences and commonalities between women. ${ }^{23}$ As Barbara Caine argues:

[They sought] to know how particular women actually experienced their domestic and social worlds; how they felt about their private and familial life; how they negotiated the social and familial structures that defined or constrained their opportunities as women; what strategies they used to follow their own interests; what support they received and whence it came; and finally what it cost them to follow their own path and to succeed in the field they chose. ${ }^{24}$

Feminist political biography therefore has the potential to go beyond the traditional biography's chronological narration and static focus on leadership and reputation; it can provide an account that captures the intricacies of women's lives in the past and present.

19 Murphy, 'Feminism and Political History', 21.

20 Susan Ware, 'Writing Women's Lives: One Historian's Perspective', Journal of Interdisciplinary History 40, no. 3 (2010): 415, doi.org/10.1162/jinh.2010.40.3.413; Chloe Ward, 'Biography, History, Agency: Where Have All the "Great Men” Gone?', Flinders Journal of History and Politics 28 (2012): 86.

21 Mineke Bosch, 'Gender and the Personal in Political Biography. Observations from a Dutch Perspective', Journal of Women's History 21, no. 4 (2009): 18, doi.org/10.1353/jowh.0.0109.

22 Bosch, 'Gender and the Personal in Political Biography', 18.

23 Ward, 'Biography, History, Agency', 84; Bosch, 'Gender and the Personal in Political Biography', 20.

24 Barbara Caine, 'Feminist Biography and Feminist History', Women's History Review 3, no. 2 (1994): 251, doi.org/ $10.1080 / 09612029400200049$. 
The writing of a political biography can be informed by a wide range of methodological approaches, from the chronological approach mentioned above, to psycho-analytic methods, journalistic accounts and historical novellas, yet these are all essentially variations of a narrative-based research methodology. ${ }^{25}$ This narrative approach, which prioritises 'flow' over analysis, is a major factor for the lack of gendered analysis in biographical works. ${ }^{26}$ However, as Murphy argues, 'political biography need not be bereft of gendered analysis' and, in fact, such analysis can significantly enrich biographies of male as well as women politicians. ${ }^{27}$ Murphy cites the example of Judith Brett's 1992 biography of Robert Menzies, in which the author presents a nuanced account of the extent to which her subject's 'understanding of manly virtue and independence ... relied upon ... power over women and over other masculinities' as a fundamental aspect of his 'social emotional map'. ${ }^{28}$ Feminist approaches to political biography such as this have clearly demonstrated that the incorporation of a gendered analysis in conventional political biography is not the sole reserve of women. Likewise, political biography is not inherently feminist just because the subject is a woman. Rather, feminist biographies ask different kinds of questions, have aims of emancipation, and often have a specific focus on power, whether that is revealing or challenging patriarchal power structures or deconstructing power imbalances between biographer and subject. Applying this to more traditional biographical work on 'significant' political figures, as in the case of Brett's biography of Menzies, results in a 'very detailed understanding of the particular social, intellectual and political circumstances which enabled their rise to prominence and their exercise of power'. ${ }^{29}$

In addition to its basis in narrative methodologies, political biography is also a highly interpretive discipline, opening the possibility for feminist analyses. Its highly qualitative nature 'directs questions about what it means to interpret and experience the world (rather than explain or predict it)'. ${ }^{30}$ Unlike political science, in which the presentation of 'truth' and 'fact' are sacrosanct, political biography eschews this concern with objectivity as 'there [is] no such thing as biographical truth'. ${ }^{31}$ Likewise, feminist biographers-following feminist approaches to research-have also challenged the very idea of a single, universal truth and instead argued for the

25 Arklay, 'Political Biography', 15.

26 Murphy, 'Feminism and Political History', 24.

27 Murphy, 'Feminism and Political History', 36.

28 Murphy, 'Feminism and Political History', 36.

29 Barbara Caine, Biography and History (London, UK: Palgrave Macmillan, 2010), 3.

30 Sonia M. Ospina and Jennifer Dodge, 'It's about Time: Catching Method up to Meaning - the Usefulness of Narrative Inquiry in Public Administration Research', Public Administration Review 65, no. 2 (2005): 144, doi.org/ 10.1111/j.1540-6210.2005.00440.x.

31 Judith McKenzie, 'Political Biography and Autobiography and the Study of Women in Politics in Canada: The Case of Political Ambition', The Journal of Legislative Studies 6, no. 4 (2000): 98, doi.org/10.1080/ 13572330008420641. 
need to recognise the coexistence of multiple truths. ${ }^{32}$ Though bias is not a major concern in biography, as it is impossible to eliminate and is therefore generally assumed to be a given, feminist biographers have stressed that it is important to acknowledge that:

The biographer is a socially-located person, one is sexed, raced, classed, aged ... And once we accept that ideas are not unique but socially produced even if individually expressed by members of a particular social, cultural and political milieux, then we can also extrapolate this to the ideas and interpretations produced by the biographer: any biographer's view is a socially located and necessarily partial one. ${ }^{33}$

Through the fundamental goal of feminist biography - to demonstrate the historical importance of women's lives-feminist biographers have therefore established innovative methodological and theoretical approaches that simultaneously refute ideas of objectivity while acknowledging the influence of the social locations of the author.

Though there have been numerous discussions around what constitutes feminist biography, and the benefits that feminist analyses bring, what would a working feminist political biographical methodology look like? In line with the feminist biographical approaches outlined above, I propose five major principles for such a methodology. First, to prioritise writing about women, trans and gender diverse political actors and activists who have been neglected or ignored by traditional political biography, or to write about male politicians through an explicitly feminist lens. Second, to recognise and deconstruct power imbalances between the researcher and subject, acknowledging the relationship between power, knowledge and language. Third, and following the second aspect, to move towards a more collaborative, cooperative and consensual method that works with the subject(s) in some capacity, aiming to achieve a more nuanced, enriched and ethical account. Fourth, to address broader themes of gender norms and inequality instead of simply describing the lives of women political actors. And fifth, to consciously retrieve the subject's 'lost subjectivity', ${ }^{34}$ which has either been historically suppressed or stereotyped through mainstream media coverage, and thereby show the intricacies of their lives and experiences.

32 Clare Hemmings, 'Affective Solidarity: Feminist Reflexivity and Political Transformation', Feminist Theory 13, no. 2 (2012): 148, doi.org/10.1177/1464700112442643.

33 Liz Stanley, The Auto/Biographical I: The Theory and Practice of Feminist Auto/Biography (Manchester: Manchester University Press, 1992), 7.

34 Kathleen Barry, 'The New Historical Syntheses: Women's Biography', Journal of Women's History 1, no. 3 (1990): 76, doi.org/10.1353/jowh.2010.0066. 


\section{Where are all the Great Women?}

Despite the promising possibilities that feminist political biography brings to the discipline, there remains an urgent need for more Australian political biographies focusing on women. To gain some understanding of the current state of the field, using the National Library of Australia's Trove catalogue, I compiled the following list to determine how many biographies have been written on women subjects in comparison to their male counterparts over the last 10 years (see Table 1). I noted the author and their gender, the political subject and their gender, the year of publication, and the book title. Of the 31 political biographies published since 2010, I discovered that only four have been written on Australian women politicians: Penny Wong (2002- ), Pauline Hanson (1997-2002; 2016- ), Patricia Giles (1981-93) and May Holman (1925-39). Initially, I thought the lack of women subjects might reflect the gender of the biographers - that a lack of women authors might explain the lack of political biographies focusing on women. The ratio of women versus male political biographers, however, is relatively even, although it should be noted that all biographies of women politicians included in this table have been written by women.

Table 1. Australian political biographies first published from 2010 to 2020

\begin{tabular}{|c|c|c|c|c|c|}
\hline Author & $\begin{array}{l}\text { Author's } \\
\text { gender }\end{array}$ & Politician & $\begin{array}{l}\text { Politician's } \\
\text { gender }\end{array}$ & Year & Title \\
\hline Tom Frame & Male & $\begin{array}{l}\text { Philip } \\
\text { Ruddock }\end{array}$ & Male & 2020 & $\begin{array}{l}\text { Philip Ruddock and the Politics } \\
\text { of Compassion }\end{array}$ \\
\hline Sean Scalmer & Male & Graham Berry & Male & 2020 & $\begin{array}{l}\text { Democratic Adventurer: } \\
\text { Graham Berry and the Making } \\
\text { of Australian Politics }\end{array}$ \\
\hline $\begin{array}{l}\text { Blanche } \\
\text { D'Alpuget }\end{array}$ & Female & Bob Hawke & Male & 2019 & $\begin{array}{l}\text { Bob Hawke: The Complete } \\
\text { Biography }\end{array}$ \\
\hline $\begin{array}{l}\text { Margaret } \\
\text { Simons }\end{array}$ & Female & Penny Wong & Female & 2019 & $\begin{array}{l}\text { Penny Wong: Passion } \\
\text { and Principle }\end{array}$ \\
\hline $\begin{array}{l}\text { Sue Pieters- } \\
\text { Hawke }\end{array}$ & Female & Bob Hawke & Male & 2019 & Remembering Bob \\
\hline Troy Bramston & Male & $\begin{array}{l}\text { Robert } \\
\text { Menzies }\end{array}$ & Male & 2019 & $\begin{array}{l}\text { Robert Menzies: The Art } \\
\text { of Politics }\end{array}$ \\
\hline $\begin{array}{l}\text { Angela } \\
\text { Woollacott }\end{array}$ & Female & Don Dunstan & Male & 2019 & $\begin{array}{l}\text { Don Dunstan: The Visionary } \\
\text { Politician who Changed } \\
\text { Australia }\end{array}$ \\
\hline Julie Suares & Female & Ben Chifley & Male & 2019 & $\begin{array}{l}\text { JB Chifley: An Ardent } \\
\text { Internationalist }\end{array}$ \\
\hline Patrick Mullins & Male & $\begin{array}{l}\text { William } \\
\text { McMahon }\end{array}$ & Male & 2018 & $\begin{array}{l}\text { Tiberius with a Telephone: } \\
\text { The Life and Stories of William } \\
\text { McMahon }\end{array}$ \\
\hline
\end{tabular}




\begin{tabular}{|c|c|c|c|c|c|}
\hline Author & $\begin{array}{l}\text { Author's } \\
\text { gender }\end{array}$ & Politician & $\begin{array}{l}\text { Politician's } \\
\text { gender }\end{array}$ & Year & Title \\
\hline John Edwards & Male & John Curtin & Male & 2017 & $\begin{array}{l}\text { John Curtin's War: The } \\
\text { Coming of War in the Pacific, } \\
\text { and Reinventing Australia }\end{array}$ \\
\hline Judith Brett & Female & Alfred Deakin & Male & 2017 & The Enigmatic Mr Deakin \\
\hline Anna Broinowski & Female & $\begin{array}{l}\text { Pauline } \\
\text { Hanson }\end{array}$ & Female & 2017 & $\begin{array}{l}\text { Please Explain: The Rise, Fall } \\
\text { and Rise Again of Pauline } \\
\text { Hanson }\end{array}$ \\
\hline $\begin{array}{l}\text { J. R. Nethercote } \\
\text { (Editor) }\end{array}$ & Male & $\begin{array}{l}\text { Robert } \\
\text { Menzies }\end{array}$ & Male & 2016 & $\begin{array}{l}\text { Menzies: The Shaping } \\
\text { of Modern Australia }\end{array}$ \\
\hline John Murphy & Male & H. V. Evatt & Male & 2016 & Evatt: A Life \\
\hline Maurice French & Male & Jack Duggan & Male & 2016 & $\begin{array}{l}\text { The Boy Who Would Be } \\
\text { Premier: A Political Biography } \\
\text { of Jack Duggan }\end{array}$ \\
\hline Troy Bramston & Male & Paul Keating & Male & 2016 & $\begin{array}{l}\text { Paul Keating: The Big-picture } \\
\text { Leader }\end{array}$ \\
\hline Karen Middleton & Female & $\begin{array}{l}\text { Anthony } \\
\text { Albanese }\end{array}$ & Male & 2016 & Albanese: Telling it Straight \\
\hline Lekkie Hopkins & Female & May Holman & Female & 2016 & $\begin{array}{l}\text { The Magnificent Life of Miss } \\
\text { May Holman Australia's First } \\
\text { Female Labor Parliamentarian }\end{array}$ \\
\hline David Day & Male & Paul Keating & Male & 2015 & Paul Keating: The Biography \\
\hline Paddy Manning & Male & $\begin{array}{l}\text { Malcolm } \\
\text { Turnbull }\end{array}$ & Male & 2015 & $\begin{array}{l}\text { Born to Rule: The Unauthorisea } \\
\text { Biography of Malcolm Turnbull }\end{array}$ \\
\hline Dino Hodge & Male & Don Dunstan & Male & 2014 & $\begin{array}{l}\text { Don Dunstan, Intimacy and } \\
\text { Liberty: A Political Biography }\end{array}$ \\
\hline Ruth Rae & & Tony Windsor & Male & 2014 & Tony Windsor: The Biography \\
\hline Patrick Weller & Male & Kevin Rudd & Male & 2014 & $\begin{array}{l}\text { Kevin Rudd: Twice Prime } \\
\text { Minister }\end{array}$ \\
\hline John Faulkner & Male & $\begin{array}{l}\text { Gough } \\
\text { Whitlam }\end{array}$ & Male & 2014 & $\begin{array}{l}\text { Gough Whitlam: A Tribute } \\
\text { 1916-2014 }\end{array}$ \\
\hline Madonna King & Female & Joe Hockey & Male & 2014 & Hockey: Not Your Average Joe \\
\hline Tracey Arklay & Female & Arthur Fadden & Male & 2014 & $\begin{array}{l}\text { Arthur Fadden: A Political } \\
\text { Silhouette }\end{array}$ \\
\hline $\begin{array}{l}\text { Mary Elizabeth } \\
\text { Calwell }\end{array}$ & Female & Arthur Calwell & Male & 2012 & I Am Bound to be True \\
\hline Susan Mitchell & Female & Tony Abbott & Male & 2011 & Tony Abbott: A Man's Man \\
\hline Anne Henderson & Female & Joseph Lyons & Male & 2011 & $\begin{array}{l}\text { Joseph Lyons: The People's } \\
\text { Prime Minister }\end{array}$ \\
\hline Grantlee Kieza & Male & $\begin{array}{l}\text { Lachlan } \\
\text { Macquarie }\end{array}$ & Male & 2010 & Macquarie \\
\hline $\begin{array}{l}\text { Lekkie Hopkins } \\
\text { and Lynn Roarty }\end{array}$ & Female & Patricia Giles & Female & 2010 & $\begin{array}{l}\text { Among the Chosen: The Life } \\
\text { Story of Pat Giles }\end{array}$ \\
\hline
\end{tabular}

Source: Trove search, National Library of Australia. 
The lack of political biographies focusing on women indicated by this table could be partially explained by a prevailing tendency to write about prime ministers-who, aside from Julia Gillard, have all been men - and about leaders of political parties (another highly masculine domain). Yet this fails to explain why neither Gillard nor any woman leader of a political party aside from One Nation's Pauline Hanson have yet been chosen as the subject for a definitive biography (though selective studies such as Jacqueline Kent's The Making of Julia Gillard do exist). ${ }^{35}$ Bearing this discrepancy in mind, I posit three key factors that could explain the lack of biographies written on Australian women politicians. First, the sociocultural factor: the lack of gender parity and equality in Australian politics. Second, the discursive factor: the enduring biographic fascination with Great Men. Lastly, the individual and interpersonal factors: the hesitation of women politicians to expose their personal lives to scrutiny and to forfeit agency over their own life stories.

It is not shocking that political biography is largely fixated on male politicians, considering the structural barriers in place that deter women from entering politics. Parliament, as Joan Acker has shown, has long been regarded as a masculine institution constructed by and for men to uphold a culture of traditional masculinity, fostering the development of an institutional sexism that empowers male politicians and disadvantages those few women who have occupied the same roles. ${ }^{36}$ This is despite formal anti-discrimination rules and regulations, which have done little to dissolve entrenched power hierarchies, norms and expectations that privilege men and masculinity. In fact, there is an outright refusal to acknowledge the extent to which the political process has been defined by 'masculinities', which are instead perceived as neutral and genderless. ${ }^{37}$ This can lead to discrimination and harassment of women in politics due to a perceived incongruence between their stereotypically feminine attributes and unacknowledged masculine occupational norms, causing them to be regarded as less competent and their performances to be devalued. ${ }^{38}$

35 Jacqueline Kent, The Making of Julia Gillard (Melbourne: Penguin, 2014 [2009]).

36 Joan Acker, 'Hierarchies, Jobs, Bodies: A Theory of Gendered Organizations', Gender and Society 4 (1990): 139-58, doi.org/10.1177/089124390004002002; Joan Acker, 'From Sex Roles to Gendered Institutions', Contemporary Sociology 21, no. 5 (1992): 565-69, doi.org/10.2307/2075528; Mary Crawford and Barbara Pini, 'Gender Equality in National Politics: The Views of Australian Male Politicians', Australian Journal of Political Science 45, no. 4 (2010): 605-21, doi.org/10.1080/10361146.2010.517177; Crawford and Pini, 'The Australian Parliament'; Natalie Galea and Barbara Gaweda, '(De)Constructing the Masculine Blueprint: The Institutional and Discursive Consequences of Male Political Dominance', Politics \& Gender 14, no. 2 (2018): 276-82, doi.org/ $10.1017 /$ S1743923X18000168.

37 Crawford and Pini, 'The Australian Parliament', 82, 94.

38 Sarah Childs, 'A Feminised Style of Politics? Women MPs in the House of Commons', The British Journal of Politics and International Relations 6, no. 1 (2004): 3-19, doi.org/10.1111/j.1467-856X.2004.00124.x; Josefina Erikson and Cecilia Josefsson, 'The Legislature as a Gendered Workplace: Exploring Members of Parliament's Experiences of Working in the Swedish Parliament', International Political Science Review 40, no. 2 (2019): 200, doi.org/10.1177/0192512117735952. 
The effects are obvious. Despite white women winning the right to vote in Commonwealth elections in 1902, they did not enter federal parliament until 1943, with the election of Dorothy Tangney to the Senate and Enid Lyons to the House of Representatives. ${ }^{39}$ Women were more successful in being elected to the state legislatures, beginning with Edith Cowan entering the Western Australian Parliament in $1921 .^{40}$ Yet the number of women in federal politics stagnated over the next few decades and, by 1990, they still only comprised 6.8 per cent of the House of Representatives and 23.3 per cent of the Senate. ${ }^{41}$ The 1990s saw a surge of women entering politics with the implementation of gender quotas and a more women-friendly Australian Labor Party (ALP), but they were still in the minority. ${ }^{42}$ After the 2019 federal election, the Senate finally achieved gender parity with 51.3 per cent women, though the House of Representatives continues to lag behind with 31.1 per cent. ${ }^{43}$ While these changes do represent shifts in cultural and social attitudes, women who occupy masculine spaces like parliament continue to be 'othered' and disparaged on a regular basis. This can further deter other women from entering politics, reinforcing the idea that parliament is a space for men. Inevitably, the significant lack of political biographies focusing on women must be at least partially attributed to this ongoing gender disparity within the political sphere itself, although it is by no means the only factor at play. Even with the recent rise in women politicians at all levels of the political hierarchy, including the highest positions of prime minister and party leader, biographers have continued to lag behind.

This brings us back to the discursive factor: the problematic endurance of the Great Man narrative. Admittedly, the influence of this narrative, as Riall has shown, did wane over the course of the twentieth century due to the adoption of new social history in the 1970s, which introduced a "Marxist emphasis on "labouring men", [and] displaced "Great Men" from their hitherto dominant role as the driving force of history. ${ }^{44}$ This inspired a widespread shift away from and repudiation of political biography as traditionally written, and especially the tendency to isolate

39 Joy McCann and Janet Wilson, 'Representation of Women in Australian Parliaments', Background Note (Canberra: Parliamentary Library, 2012), 10, www.aph.gov.au/About_Parliament/Parliamentary_Departments/ Parliamentary_Library/pubs/BN/2011-2012/Womeninparliament\#_Toc318895772.

40 Elizabeth van Acker, Different Voices: Gender and Politics in Australia (South Yarra: Macmillan Education Australia, 1999), 74.

41 Blair Williams and Marian Sawer, 'Rainbow Labor and a Purple Policy Launch: Gender and Sexuality Issues', in Double Disillusion: The 2016 Australian Federal Election, ed. Anika Gauja et al. (Canberra: ANU Press, 2018), 644, doi.org/10.22459/DD.04.2018.28.

42 Williams and Sawer, 'Rainbow Labor and a Purple Policy Launch', 644.

43 Anna Hough, 'Composition of Australian Parliaments by Party and Gender: A Quick Guide', Research Paper (Canberra: Parliamentary Library, 2020), www.aph.gov.au/About_Parliament/Parliamentary_Departments/ Parliamentary_Library/pubs/rp/rp2021/Quick_Guides/CompositionPartyGender.

44 Riall, 'The Shallow End of History?', 379. 
the individual. ${ }^{45}$ The new biographic models that followed this shift, however, still overlooked women's roles throughout history, and 'the focus on males-great or labouring, individual or collective-was common to both approaches' ${ }^{46}$ Though the Great Man narrative has often been discussed and derided among political biographers, especially in recent decades, the same authors nevertheless continue to write predominantly about men's lives, tacitly endorsing Carlyle's vision of history unfolding 'through the effects of dominant males' and of leadership as 'irredeemably masculine' ${ }^{47}$

As shown in the table above, the overwhelming majority of Australian political biographies published in the last decade have focused on male subjects, and especially on former prime ministers. For example, two biographies have been written on former Labor prime ministers Paul Keating (in 2015 and 2016) and Bob Hawke (both in 2019) and two on former Liberal prime minister Robert Menzies (in 2016 and 2019), in addition to the stack of already published biographies on these leaders. Yet another biography has been written on Gough Whitlam (2014), and even former South Australian premier Don Dunstan has been the subject of two biographies published just five years apart, in 2014 and 2019. Furthermore, it should be noted that this table only includes the first editions of the political biographies listed - there were numerous reprints of biographies of former male prime ministers, particularly Menzies, Whitlam and Hawke, published during the same time frame. There also appears to be a penchant within this time frame for writing about the lives of the Great Men of Australia's colonial history, such as early New South Wales governor Lachlan Macquarie (1810-21) and early Victorian premier Graham Berry (1875, 1877-80, 1880-81), and twentieth-century Australian prime ministers, like Alfred Deakin (1905-08), Joseph Lyons (1932-39) and Ben Chifley (1945-49). The overabundance of biographies focusing on foundational patriarchs such as these demonstrates the continuity of a trend towards idolising the supposed 'Fathers of the Nation'-the Great Men who built and shaped Australia. The hagiographic and frequently nationalistic basis of this tendency appears evident in the titles of some of these biographies, such as J. R. Nethercote's Menzies: The Shaping of Modern Australia (2016), Angela Woollacott's Don Dunstan: The Visionary Politician Who Changed Australia (2019) and Sean Scalmer's Democratic Adventurer: Graham Berry and the Making of Australian Politics (2020), although each text presents a historical case for the title's claim. Echoing Carlyle's theory that great men were heroes sent by God to shape the world, the above titles insinuate that these leaders fundamentally fashioned and transformed the supposed 'terra nullius' of Australia.

45 Anna Green and Kathleen Troup, The Houses of History: A Critical Reader in Twentieth-Century History and Theory (Manchester: Manchester University Press, 1999), 87.

46 Riall, 'The Shallow End of History?', 380.

47 Grint, 'A History of Leadership', 8. 
Beyond the discursive and sociocultural, the final factor that I have identified as a possible explanation for the under-representation of women subjects in Australian political biography takes us to the level of the individual and interpersonal. Simply put, women politicians might be hesitant to expose their private lives to the same extent as their male counterparts. I have shown in previously published studies on the issue of gendered representation that women politicians frequently experience gendered, and often sexist, media coverage that focuses on their gender, appearance, sexuality, family and private lives in a way that delegitimises them in their political roles. ${ }^{48}$ Coverage of a male politician's personal life may result in opportunities for image-making and can further humanise him, but for a woman, it carries the potential to ensnare in a gendered double bind, inviting judgement about personal choices as a reflection of political and professional capability. Take the family, for example. While male politicians' families and their roles as husbands and fathers are merely seen as an extension of their identity, women are to a large extent defined by their marital and parental status, demonstrating that 'maternity remains more relevant than paternity. ${ }^{49}$ Such gendered emphasis on women politicians' family lives is problematic because it implicitly portrays their choice of professional over domestic fulfilment as an abnormal aberration. Since the personal is a fundamental aspect of political biographies, it is hardly shocking that women in politics might be hesitant to cede agency over their own story and share their private lives with the world. As Mineke Bosch makes clear, 'women's quite aberrant private lives ... could turn into liabilities for their public careers. Here, also, their biographies became problematic'. ${ }^{50}$

\section{The autobiographical turn}

We have established, then, that there is currently a notable lack of Australian political biographies on women subjects, despite a recent rise in the number of women entering politics and even ascending to its upper echelons. We could reasonably assume, however, that a sizeable proportion of at least half the Australian population have some interest in the lives and careers of those women who have made a name for themselves in the political sphere. So, where exactly has this interest been directed? If we turn our attention from the accounts of political women written

\footnotetext{
48 Blair Williams, 'A Gendered Media Analysis of the Prime Ministerial Ascension of Gillard and Turnbull: He's “Taken Back the Reins” and She's "a Backstabbing” Murderer', Australian Journal of Political Science 52, no. 4 (2017): 550-64, doi.org/10.1080/10361146.2017.1374347; Blair Williams, 'A Tale of Two Women: A Comparative Gendered Media Analysis of UK Prime Ministers Margaret Thatcher and Theresa May', Parliamentary Affairs 74, no. 2 (26 April 2020), doi.org/10.1093/pa/gsaa008; Blair Williams, 'It's a Man's World at the Top: Gendered Media Representations of Julia Gillard and Helen Clark', Feminist Media Studies, 10 November 2020, doi.org/ 10.1080/14680777.2020.1842482.

49 Kathleen Hall Jamieson, Beyond the Double Bind: Women and Leadership (Oxford: Oxford University Press, 1995), 168.

50 Bosch, 'Gender and the Personal in Political Biography', 23.
} 
by professional writers to those they have penned themselves, a further level of nuance can be added to our analysis by a growing trend in recent years that I refer to here as an autobiographical turn. Autobiographies allow political women to reassert their agency and reclaim their public identity by telling their own life story. The most notable example of this turn is Julia Gillard's memoir My Story, in which she reflects on her life, her time in politics and the turbulent Rudd-Gillard-Rudd era. ${ }^{51}$ To establish the extent of this phenomenon, I returned to Trove, this time searching for autobiographies written by Australian women politicians during the same 10 years. In all, 12 autobiographies have been published over the last decade by women premiers, party leaders, federal and state MPs and senators, lord mayors and, of course, our first and currently only woman prime minister (see Table 2).

\section{Table 2. Australian women political autobiographies/memoirs first published from 2010 to 2020}

\begin{tabular}{|l|l|l|}
\hline Politician & Year & Title \\
\hline Cathy McGowan & 2020 & Cathy Goes to Canberra: Doing Politics Differently \\
\hline Fiona Patten & 2018 & $\begin{array}{l}\text { Sex, Drugs and the Electoral Roll: My Unlikely Journey from Sex } \\
\text { Worker to Member of Parliament }\end{array}$ \\
\hline Anne Aly & 2018 & $\begin{array}{l}\text { Finding My Place: From Cairo to Canberra-the Irresistible Story of an } \\
\text { Irrepressible Woman }\end{array}$ \\
\hline Roslyn Kelly & 2017 & Ros Kelly: A Passionate Life \\
\hline Christine Milne & 2017 & Activist Life \\
\hline Sallyanne Atkinson & 2016 & No Job for a Woman \\
\hline Joan Child & 2015 & Joan: Child of Labor \\
\hline Anna Bligh & 2015 & Through the Wall \\
\hline Julia Gillard & 2014 & My Story \\
\hline Carolyn Hirsh & 2014 & Politics, Death and Addiction \\
\hline Maxine McKew & 2012 & Tales from the Political Trenches \\
\hline Mary Delahunty & 2010 & Public Life, Private Grief: A Memoir of Political Life and Loss \\
\hline
\end{tabular}

Source: Trove, National Library of Australia.

Autobiography can be a valuable means for women politicians to 'recover' their voices, often excluded from canonical accounts of history. ${ }^{52}$ It can 'be a way for a protagonist herself to show how competent she [is] and at the same time ... to hide her private life, either by actually ignoring it or by describing it as perfect'. ${ }^{53}$ Again, a glance at the titles of the texts listed in Table 2 reveals how these politicians

51 Julia Gillard, My Story (North Sydney, NSW: Random House Australia, 2014).

52 Annie Devenish, 'Performing the Political Self: A Study of Identity Making and Self Representation in the Autobiographies of India's First Generation of Parliamentary Women', Women's History Review 22, no. 2 (2013): 282, doi.org/10.1080/09612025.2012.726116.

53 Anneke Ribberink, Tiina Kinnunen, Kirsti Niskanen and Angelika Schaser, 'Introduction: Gender and Politics in Auto/Biographies', European Journal of Life Writing 5 (2016): 5, doi.org/10.5463/ejlw.5.205. 
have used autobiography to take control of their public image while resisting and exposing the sexist discourses through the perpetuation of which they have been excluded or othered. Cathy McGowan's title, for example, notes how she 'does politics differently' while Sallyanne Atkinson's encapsulates her experience of repeatedly being told that her occupational ambitions were 'no job for a woman'. These autobiographies also eschew the stereotyping labels generally given to women in politics, such as 'hysterical', 'emotional' or 'compassionate', instead identifying their subjects with more empowering descriptors such as 'irrepressible', 'passionate' and 'activist'. ${ }^{54}$ These titles immediately make clear that the women whose stories are told in each text have aimed to use the medium of autobiography to reclaim their stories from sexist stereotyping or vilification.

A decade earlier, former leader of the Democrats Cheryl Kernot published her autobiography Speaking for Myself Again. ${ }^{55}$ In the span of her lengthy political career, Kernot's public image shifted from that of a successful and popular politician - a media favourite - to someone who was publicly shamed and 'stoned'. ${ }^{56}$ Kernot's abrupt 'defection' to the ALP in 1997 received widespread critique and largely triggered her fall from 'media starlet' to 'media tart'. ${ }^{57}$ As Julia Baird notes:

once she was heralded as the woman who could win the election for Labor, the media—goaded by her opponents—sank their teeth into her reputation and shook it, which clearly contributed to what was a very public unravelling of a woman once widely respected..$^{58}$

Like many women politicians before and after her, Kernot faced the sexist malice of the media circus. Clouded by scandals and speculation, she sought with her autobiography to reclaim her voice and share her own perspective of her time in the ALP. The first two pages make this explicit while also pointing to the gendered double standards that women in politics endure. The first page reproduces a political cartoon by Cathy Wilcox stating what 'nice girls' are supposed to avoid, concluding with the tongue-in-cheek statement, 'but MOST OF ALL, if a nice girl does any of those things, she should have the DECENCY to leak it to the media first!' The opposing page is the Author's Note, in which Kernot states that she has 'written this book to give history and those who interpret it a chance to hear the other side $\ldots$ This is the story of a woman, who also happens to be a politician ... These are my words. ${ }^{59}$

\footnotetext{
54 Monica C. Schneider and Angela L. Bos, 'Measuring Stereotypes of Female Politicians', Political Psychology 35, no. 2 (2014): 245-66, doi.org/10.1111/pops. 12040.

55 Cheryl Kernot, Speaking for Myself Again: Four Years with Labor and Beyond (Pymble, NSW: HarperCollins, 2002).

56 Julia Baird, Media Tarts, How the Australian Press Frames Female Politicians (Melbourne: Scribe, 2004), 164.

57 Baird, Media Tarts, 164.

58 Baird, Media Tarts, 165.

59 Kernot, Speaking for Myself Again, ix.
} 
Throughout her autobiography, Kernot fights back against the media sexism that she experienced, particularly in the last few years of her political career. One chapter, 'Red Dress, Red Hair and All That Rubbish', examines the media's gender bias in their coverage of her actions. From hyper-sexualisation and an apparent obsession with the red dress that she notoriously wore in a Woman's Weekly photoshoot in 1998, to the incessant focus on her personal romantic life, this bias prompts Kernot to ask, 'why did some in the media pursue me so fiercely?' ${ }^{0} 0$ The final chapter, 'Women, Politics and Pedestals', similarly critiques the sexist assumptions placed on women politicians more generally. Examining sexist stereotypes and expectations in politics and the direct correlation between these and a lack of women in political leadership, Kernot points to the 'dominant masculine values and style ... starkly evident in Australia's media', where 'women politicians have had a bad deal from the media's preoccupation with political style over policy substance. ${ }^{61}$ By concluding with this chapter, Kernot not only reclaims her voice and perspective within a maledominated political culture, but reveals the damaging effect this has on all women in politics.

Women in many spheres of public life have used autobiography to write themselves into history and make the invisible visible, yet women in politics, above all, present a clear case study in the extent to which this form of biography can be used to fight against prejudice and assumption. ${ }^{62}$ Gillard's autobiography is, once again, a valuable case in point. As Australia’s first woman prime minister, Gillard was subjected to an overwhelming volume of misogynistic media coverage and gendered backlash from colleagues, the mainstream media, and the public she served. Her path to the prime ministerial role in 2010, gained by challenging her predecessor Rudd, was seen as unusual, especially for a woman, and garnered widespread attention. Both immediately after this and throughout her tenure as prime minister, she experienced undue amounts of gendered, often highly negative and even defamatory media coverage that focused on her gender, appearance, childlessness, sexuality, family life and relationship status. ${ }^{63}$

It is therefore unsurprising, given her treatment in the media, that Gillard opted to write an autobiography to recover her voice, rather than place her trust in a biographer. My Story, presented as her version of the defining events in her political career, achieves this recovery not only through the presentation of her authorial voice but also through several innovations on the conventional biographic format that set the text apart from those dedicated to the lives of Great Men. Most notably,

\footnotetext{
60 Kernot, Speaking for Myself Again, 141.

61 Kernot, Speaking for Myself Again, 232.

62 Sidonie Smith and Julia Watson, 'Introduction: Situating Subjectivity in Women's Autobiographical Practices', in Women, Autobiography, Theory: A Reader (Madison: The University of Wisconsin Press, 1998), 5.

63 Williams, 'It's a Man's World at the Top'; Williams, 'A Gendered Media Analysis of the Prime Ministerial Ascension of Gillard and Turnbull'.
} 
Gillard does not present a traditional chronological narrative of her life story, choosing instead to divide the book into two thematic sections: 'Section OneHow I did it' and 'Section Two-Why I did it'. In the first section, she explains how she became prime minister and recalls her experience of the 2010 election campaign, her turbulent relationship with Rudd, and the resilience she needed to succeed in politics. The personal is not emphasised; she does not wax lyrical about the extent to which her lineage, childhood, family, and personal relationships may have influenced her political aspirations and ideology, as commonly seen in traditional political biographies. Instead, she strategically deploys personal anecdotes only as exemplary illustrations of how or why she entered politics. For example, in Chapter 8 ('My Purpose') Gillard states that 'my focus on work comes from childhood and my own personal experience' and recounts a story about her father's working-class work ethic and unionism. ${ }^{64}$ She also mentions her appearance throughout as a way to add humour to her narrative, rather than as an objectifying or derogatory tool. Chapter 2 ('The First Days'), for example, opens with the words 'Good day for redheads!' that she famously uttered on The 7:30 Report on her first day, subsequently noting that 'joking about red hair became one of the routines of my prime ministership'. ${ }^{65}$ Through the medium of autobiography, Gillard reclaims her personal life and appearance in a way that would not be possible in a traditional biography.

Even the title of Gillard's autobiography-My Story—represents a reclamation in terms that resonate throughout the book. Chapter 6 ('The Curious Question of Gender'), for example, is dedicated to calling out the gendered double standards and misogyny that she experienced as prime minister, from Opposition Leader Tony Abbott stating that she should 'make an honest woman of herself' to shock jock Alan Jones asserting that she should be 'put in a chaff bag and thrown out to sea'. ${ }^{66}$ Gillard notes that 'words were used to spin an image of me that fitted with our culture's worst caricatures about women' and she, as a 'woman wielding power' meant that she 'must be the bad woman, a scheming shrew, a heartless harridan or a lying bitch'. ${ }^{67}$ In this chapter, as in others, Gillard reclaimed her voice in spite of the sexism and misogyny she experienced, using it to inspire hope that the future will be better for the women who follow her lead.

It is important for women politicians to write their own stories, for the reasons outlined above. However, that does not mean that we should give up on political biographies of women. Rather, we should focus on transforming political biographies to become more inclusive, less hierarchical and more feminist, thereby encouraging women political actors to give consent for their stories to be told. Instead of viewing

64 Gillard, My Story, 137.

65 Gillard, My Story, 25.

66 Gillard, My Story, 106.

67 Gillard, My Story, 106-7. 
politicians as neutral subjects to be analysed, political biographers could seek to reduce power imbalances and work with their subjects in a collaborative manner that would result in a more nuanced, ethical and more compelling form of biography.

\section{Biographies of political women}

The few biographies of Australian women politicians that have been published in the last 10 years vary considerably depending on when and by whom they were written. Despite their differences, however, while political biographies of male politicians have 'become enriched with all sorts of information on their private lives: their hobbies and habits, political tastes, and to some extent also their family life', those written about women politicians generally 'still suffer from an over-personalisation of public women in the past and present ${ }^{6}{ }^{68}$ There is a persistent tendency to highlight a woman's family, marital status and intimate life in a way that is far more damaging than it would likely be for her male counterparts. Some understanding of this and other defining traits shared by recent biographies of Australian women politicians, as well as the distinctions that arise from authorial and chronological differences, can be gained by comparing and analysing Broinowski's Please Explain and Simons's Penny Wong through a feminist analysis. ${ }^{69}$ Although, of course, the clearest point of contrast between these two texts lies in their representations of racial identity; the magnitude and complexity of this issue far exceeds the limits of the current argument and so has not been addressed in depth.

Before analysing the features of their respective biographies, it should be noted that Wong and Hanson cooperated with their biographers to differing degrees. While Hanson was suspicious of the author's intentions, she nevertheless allowed Broinowski complete access to her and her 'Fed Up' election campaign in 2015, inviting her to travel with her around New South Wales and Queensland. While reading Simons's biography, on the other hand, it becomes clear that Wong was uncomfortable with the very idea of its publication. Simons opens the text by noting that 'Penny Wong did not want this book to be written', going on to describe her numerous failed attempts to contact Wong for research interviews. ${ }^{70}$ It was not until Simons had nearly finished writing the book, she admits, that Wong finally, albeit reluctantly, agreed to meet in person, granting six interviews over an eight-month period. According to Simons, Wong was hesitant because the biography would:

68 Bosch, 'Gender and the Personal in Political Biography', 13.

69 Anna Broinwoski, Please Explain: The Rise, Fall and Rise Again of Pauline Hanson (Docklands, Vic.: Penguin Random House Australia, 2017); Margaret Simons, Penny Wong: Passion and Principle (Carlton, Vic.: Black Inc., 2019).

70 Simons, Penny Wong, iv. 
give a version of her that she would have to deal with and live with and which would be accepted as true_-and it would not be how she saw herself ... it would not be only a public image but 'your version of me' ${ }^{71}$

Simons also very perceptively observes that there are relatively few political advantages, and many disadvantages, for Wong to have a biography published at this point in her career. Above all, it could potentially have presented her opponents with a detailed account of her life, which 'must be an alarming prospect' for someone who has consistently faced media scrutiny throughout her political career. ${ }^{72}$ It might also have pigeonholed Wong as an Asian, lesbian woman and thereby further heightened the public perception of her divergence from the hegemonic political norm of the white, heterosexual man, thus increasing her vulnerability in the political sphere. ${ }^{73}$ In the concluding pages of the book, however, Wong remarks that the possibility of such negative impact also in fact encouraged her eventual decision to cooperate with Simons, as she saw the potential for her to be represented as a 'high-profile gay ... role model for others', thereby transforming these antiquated norms. ${ }^{74}$

This raises multiple questions around the issue of consent in feminist work. What is the importance of consent in feminist biographies? Can a biography be feminist if it is written without - or against — the consent of its subject? Despite understanding and sympathising with Wong's reservations, why did Simons persist? Informed consent is integral to feminist research as it 'makes explicit the importance of respect for those taking part' and protects against exploitation. ${ }^{75}$ Feminist methodology also highlights the importance of recognising power imbalances between researcher and researched. Though Wong, as a member of the political elite, does not lack power in comparison to Simons, she also experiences a form of powerlessness as her story is being told without her initial consent. There would have been other, less ethically problematic, ways of telling Wong's story. For example, rather than focusing on Wong as an 'exceptional' individual, Simons could have situated her story in the wider context of Australian LGBTQIA+ pioneers, activists and politicians. ${ }^{76}$ A detailed analysis of collective lives 'offers one of the best ways to explore ... the importance of gender, race and class', and arguably sexuality, and would have shifted the focus from someone who did not consent to a biography to the broader movement. ${ }^{77}$

\footnotetext{
71 Simons, Penny Wong, xii.

72 Simons, Penny Wong, xi.

73 Ribberink et al., 'Introduction: Gender and Politics in Auto/Biographies', 3.

74 Simons, Penny Wong, 317.

75 Kathi N. Miner, Toby Epstein Jayaratne, Amanda Pesonen and Lauren Zurbrugg, 'Chapter 12. Using Survey Research as a Quantitative Method for Feminist Social Change', in Handbook of Feminist Research: Theory and Praxis, 2nd ed., ed. Sharlene Nagy Hesse-Biber (London: SAGE Publications, 2012), 237-63, doi.org/10.4135/ $9781483384740 . n 12$.

76 Bosch, 'Gender and the Personal in Political Biography', 20.

77 Caine, Biography and History, 3.
} 
Aside from these differences in their relationship with their subject, both books are authored by academics whose writing appears to have been influenced by feminist approaches to political biography. This is most evident in the Preface to each text, in which Simons and Broinowski clarify their political stances and social locations in line with the idea of reflexivity. Reflexivity, as a theoretical concept, reflects a key component of feminist knowledge production, in which emphasis is conventionally placed on the need for readers to be aware of the extent to which a researcher's subjectivity and worldview can influence their research. Feminist scholars argue that it is crucial for researchers to be reflexive, or aware of their privileges and life experiences to ensure that their research does not perpetuate the inequalities they seek to change or subvert. ${ }^{78}$ As Rae Wear argues, 'writing political biography almost always involves a degree of self-exploration: there is a little bit of autobiography lurking beneath the surface of every biography'. ${ }^{79}$ In her Preface, Simons notes that:

Historian and biographer Blanche Wiesen Cook has remarked that for biographers all choices made in writing are autobiographical. So it might be relevant that I, too, arrived in Adelaide at the age of eight and was bullied at school-though in my case for an English accent rather than because of racism. I went to the University of Adelaide, as a contemporary of Julia Gillard, ten years before Penny Wong. I have Jewish ancestry. While I am not in any real sense Jewish, I was raised with a strong awareness of the great evil of racism. ${ }^{80}$

With this reflexive statement, Simons highlights her self-perceived similarities with her subject in an effort to relate to Wong on a personal level and to underline why she, specifically, is writing this biography by indicating how her social locations might influence her version of Wong's life story. The way Simons discusses Wong here also indicates a clear admiration and respect that remains apparent throughout the text.

Broinowski's Preface, on the other hand, is slightly more ambiguous. Like Simons, she states her reflexive position, allowing the reader to evaluate how this might influence her account of Hanson. Her self-positioning is made, however, in the form of a recounted conversation with Hanson, rather than directly to the reader:

78 Paul Baker, 'Discourse and Gender', in The Bloomsbury Companion to Discourse Analysis, ed. Ken Hyland and Brian Paltridge (London: Bloomsbury, 2011), 203; Michelle M. Lazar, 'Politicizing Gender in Discourse: Feminist Critical Discourse Analysis as Political Perspective and Praxis', in Feminist Critical Discourse Analysis: Gender, Power and Ideology in Discourse, ed. Michelle M. Lazar (Hampshire: Palgrave Macmillan, 2005), 15, doi.org/ 10.1057/9780230599901_1.

79 Ray Wear, 'Writing Political Biography', in Australian Political Lives: Chronicling Political Careers and Administrative History, ed. Tracey Arklay, John Nethercote and John Wanna (Canberra: ANU E Press, 2006), 73, doi.org/10.22459/APL.10.2006.11.

80 Simons, Penny Wong, xii. 
We began to talk, and Hanson was frosty and monosyllabic. But when I told her I was a pro-refugee, pro-environment, pro-reconciliation leftie who had grown up in Asia and disagreed with almost everything she said, she decided to trust me. Hanson prides herself on being a straight talker and values honesty in others. ${ }^{81}$

Towards the end of her Preface, Broinowski also reaffirms that she fundamentally disagrees with Hanson's politics and clarifies her reasons for writing this biography:

I am not endorsing Hanson's views, nor am I giving her an uncritical platform. I am deliberately engaging with the debate that the majority of tolerant Australian voters, on all sides of politics, refused to directly engage with the first time Hanson divided Australia, in the $1990 \mathrm{~s} .{ }^{82}$

Yet Broinowski also frequently compliments certain aspects of Hanson's persona, stating that she 'has undeniable X-factor' and is an 'irascible, unique and resilient woman'. ${ }^{83}$ It is not unusual for biographers to be drawn to the chosen subject for numerous, often personal, reasons. ${ }^{84}$ Nor is it uncommon to begin a project disliking the subject only to gain sympathy and admiration through knowing them more intimately. ${ }^{85}$ In neither case, however, does such reflexivity serve to create what might be termed a Great Woman narrative, contributing instead to the generation of a more even power dynamic between biographer and subject. Additionally, in her 'Epilogue', Broinowski concludes by noting that any sympathy she may have felt for Hanson when they first met in 2009 evaporated following her re-election for the first time since 1998 in the 2016 federal election, prompting Broinowski to realise 'the damage she [Hanson] continues to inflict on this once open-hearted and proudly multicultural country, and the platform she's been allowed to wield, are, to me, both unforgivable and horrific' ${ }^{86}$

In addition to their academic background and apparent deference to feminist biographical approaches, Simons and Broinowski can also be compared for their shared emphasis on the appearance of their subjects, though again with some notable points of distinction. With my previous research, I have demonstrated the extent to which the media often focuses on the appearance of women politicians to draw further attention to their supposed transgressive gender performances-as women entering a highly male-dominated institution, governed around masculine norms-

81 Broinwoski, Please Explain, 2.

82 Broinwoski, Please Explain, 5-6.

83 Broinwoski, Please Explain, 1, 5.

84 Tracey Arklay, John Nethercote and John Wanna, 'Preface', in Australian Political Lives: Chronicling Political Careers and Administrative History, ed. Tracey Arklay, John Nethercote and John Wanna (Canberra: ANU E Press, 2006), xi, doi.org/10.22459/APL.10.2006.

85 Philip A. Selth, 'Political Biographies and Administrative Memoirs: Some Concluding Comments', in Australian Political Lives: Chronicling Political Careers and Administrative History, ed. Tracey Arklay, John Nethercote and John Wanna (Canberra: ANU E Press, 2006), 110, doi.org/10.22459/APL.10.2006.17.

86 Broinwoski, Please Explain, 308. 
and thereby to trivialise them in their political roles. ${ }^{87}$ By focusing on their feminine image, or lack thereof, women are physically marked as 'other' and are subjected to impossible beauty ideals and subsequent scrutiny when they fail to conform to these unrealistic expectations. This bind demonstrates the near impossibility for women to escape the objectifying male gaze that reduces them to novelties, while their male counterparts continue to be regarded as the norm.

This kind of sexist coverage is not solely confined to the mainstream press and appears to be a common trope in political biographies of women as well. Broinowski's biography appears to echo broader sexist tendencies, particularly where she focuses on and sexualises Hanson's appearance. For example, the second paragraph in the Preface reads:

It was 9 a.m. on a Sunday but Hanson answered the door dressed for a cocktail party, in head-to-toe white with matching stilettos and pearls. At fifty-four, she was trim and impeccably made-up, her muscled hands the only evidence of the years of hard labour she'd put into her Ipswich fish and chip shop. ${ }^{88}$

Hanson's appearance is here described before introducing her political role or notoriety as leader and founder of a populist right-wing minor party, reinforcing the idea that '[women's] policies and professional roles are relegated to a position of secondary importance'. ${ }^{89}$ It is also important to acknowledge that Hanson did exercise some agency in her public and media representation, often seeking to project herself in a certain way to further her aims. As political scientist Elizabeth van Acker notes, 'while Hanson often appeared as a vulnerable woman with a shaky voice, she also flaunted her sexuality, combining her femininity with a strong character'. ${ }^{90}$ She used the media to 'promote her own celebrity' and obviously 'understood the importance of exploiting her looks, thereby ensuring attention from reporters'. ${ }^{91}$ Hanson's embodiment of a traditional, white femininity further promoted her farright populist xenophobic ideology. However, while it is useful for Broinowski to analyse Hanson's use of her appearance, 'too often the details seem included solely for titillation rather than integrated into an overall interpretation of someone's life ... [it is] simply the personal without the political'. ${ }^{92}$

87 Williams, 'A Comparative Gendered Media Analysis of UK Prime Ministers Margaret Thatcher and Theresa May'; Williams, 'Gendered Media Representations of Julia Gillard and Helen Clark'.

88 Broinwoski, Please Explain, 1.

89 Williams, 'A Comparative Gendered Media Analysis of UK Prime Ministers Margaret Thatcher and Theresa May', 14.

90 Elizabeth van Acker, 'Media Representations of Women Politicians in Australia and New Zealand: High Expectations, Hostility or Stardom', Policy and Society 22, no. 1 (2003): 126, doi.org/10.1016/S1449-4035(03) 70016-2.

91 van Acker, 'Media Representations of Women Politicians in Australia and New Zealand', 127.

92 Ware, 'Writing Women's Lives', 418. 
An emphasis on Hanson's appearance remains apparent throughout Broinowski's biography. This is particularly evident in her description of Hanson as a 'pretty' child 'born with an unusually telegenic bone structure', of her figure at 61 as 'fashionably toned', and other such objectifying passages of exposition. ${ }^{93}$ Broinowski also dedicates numerous pages to a careful description of Hanson's outfits, from her first term in politics in the late 1990s. One jacket in particular is described as an 'uber-feminine cut' in a 'cheap, eye-catching fabric [which] encapsulates the sartorial style that would see Hanson's wardrobe dissected almost as widely as her policies during her first federal term. ${ }^{94}$ Age is another characteristic often commented on by the mainstream press and in this biography, with Broinowski frequently noting that Hanson is attractive for her age. It is common for women's age to be commented on when examining their appearance, particularly the age of women in the public eye, as their worth is customarily attached to their attractiveness and younger women are popularly perceived as more attractive and therefore more desirable..$^{55}$ This kind of levelling discourse is generally not found in political biographies of men, in which personal anecdote or detail tends to support a mythic depiction.

A comparable preoccupation with sartorial style can be noted in Simons's biography of Wong, but this differs greatly in frequency and tone. In Chapter 2 ('Butterflies and Bullies'), for example, Simons describes a photograph of a young Wong serving tea to her grandmother:

Penny wears a pink ruffled dress. She is kneeling on a cushion in front of the old woman, a tray solemnly extended. [Her grandmother] Lai is sitting ramrod straight, with a stern expression, her head inclined to the little girl. ${ }^{96}$

The overall message in this paragraph is not to communicate what Wong was wearing, but to affirm the strong bond and love that she shared with her grandmother. This photograph is also then used as a platform from which to explore Wong's immigrant background and the racism she experienced after moving to Australia as a child. This narrative, threaded throughout the biography, takes pride of place in the depiction in Chapter 7 ('A New Voice') of Wong's maiden speech to the Senate in 2002. Simons describes the outfit that Wong chose for this event as follows:

Standing in the red Senate chamber, Penny looked younger than her thirty-three years. She had yet to adopt her current work uniform of slacks, well-cut jackets, immaculate haircut and simple shirts. She wore a maroon jacket over a black dress, a white necklace and simple pearl earrings. ${ }^{97}$

93 Broinwoski, Please Explain, 47, 50.

94 Broinwoski, Please Explain, 51.

95 Jamieson, Beyond the Double Bind, 147.

96 Simons, Penny Wong, 26.

97 Simons, Penny Wong, 121. 
Simons notes that Wong appeared nervous but that the overall theme of her speech was one of compassion and the absence of this quality in an Australia governed by John Howard, who won by focusing the debate on issues of border protection in the wake of 9/11 and the Children Overboard and Tampa affairs. In contrast to Broinowski's focus on Hanson's physical attractiveness, Simons's preoccupation with Wong's appearance is neither central to the narrative nor disproportionately concerned with her gender and appearance at the expense of her politics.

Despite the inspiration that both authors have drawn from feminist approaches to political biography, then, both Simons and Broinowski continue to focus on the personal to an extent that would likely be considered unusual or even invasive for a male subject. In her biography of Hanson, Broinowski repeatedly emphasises the latter's telegenic appearance and the signature clothes she wore during her political term in the 1990s. While Hanson seems to have been happy to show Broinowski some of these outfits, the way in which Broinowski has chosen to describe them and her continual references to Hanson's appearance throughout her life could be considered objectifying. At times, Hanson is stripped of her agency and represented as little more than a set of clothes or an attractive physical figure-an object for the camera lens. Wong, on the other hand, takes a much more active role in Simons's biography, despite her initial reluctance to agree to the writing of her life story. Her appearance is only mentioned in passing and in a way that contributes to her overall narrative; Wong is mythologised as an inspirational progressive politician and a committed advocate for sexual and racial diversity and inclusion. Perhaps this difference between the two biographies could be explained by the authors' divergent perspectives on their subjects and more general social perceptions of each politician. Broinowski might have been more willing to objectify Hanson because of their vehemently opposing ideologies while Simons appeared to have maintained a deep respect for Wong, who is also far more electorally popular and socially palatable than Hanson. Despite this, however, both Hanson and Wong are written about in a way that sets them apart from their male counterparts. Although personal detail is, of course, included in biographies of the latter, the tone, attitude and implications are vastly different. Personal detail in a biography of a man mythologises, while the same level of detail in a biography of a woman tends to demythologise.

\section{Conclusions: Can biographers in Australia do better in this field?}

Following Mineke Bosch and reflecting on some of the prevailing tendencies revealed by the comparison of Hanson's and Wong's biographies, I propose a list of 'dos and don'ts' for future biographers of women politicians. First, biographers would be well advised to avoid an 'asymmetrical emphasis on the relation between the public 
person and the private personality in the lives of men and women' ${ }^{98}$ While political biographers must meld their subjects' private and public lives to a certain extent to understand the influences that have shaped their view of the world and, in turn, their politics, this has particularly gendered ramifications for political women. Men are rarely positioned as gendered subjects while women are far too often defined by their private lives alone, emphasising their (gendered) difference from the political norm. Second, biographers could endeavour to avoid attributing a woman's political career and successes to her '(sublimated) lack of (sexual) love or motherhood' or other such personal issues. ${ }^{99}$ Although personal experiences-such as the racism that Wong faced throughout her childhood or Hanson's relationship with her father-may influence a woman's political aspirations, it is reductive and sexist to wholly attribute their success to these events. The aim should be to capture their life story without reducing them to their life experience. Third, biographers seeking to represent political women fairly could refrain from describing their appearance or sartorial choices unless these are directly relevant to the narrative. Simons's biography of Wong is an excellent example of the latter, while Broinowski often mentioned Hanson's appearance when this had little relation to the overall story aside from drawing attention to her physical attractiveness. It is imperative for the biographers of women politicians to understand the ramifications of emphasising the appearance of their subjects; such emphasis trivialises them and draws attention to their gender while their male counterparts are portrayed as neutral and genderless.

Beyond this, however, there is a need to move past the discursive construct of the Great Man narrative, which remains a palpable presence despite increasing criticism. Framing male political leaders as Great Men who have irrevocably shaped the historic development of modern Australia discursively and literally excludes women, who are not considered to be Great because this narrative is inextricably tied to men and masculinity. The lack of political biographies written on women is simultaneously a result of and a contributor to this myth. However, even if more biographies were written on women politicians, this would not change the fact that their male counterparts, especially former prime ministers, are still framed as Great. In order to achieve parity for women and male politicians in the field of biographies, there is a need to develop a more inclusive discursive model. Feminist approaches to political biography, such as the departure from a hyper-individualistic focus or the cultivation of author reflexivity, offer one possible pathway to this goal and can greatly enrich analysis while providing a more insightful narrative overall. Yet these changes need to be made to all political biographiesincluding those of men. After all, 'if we do not develop the new biographical stories we want to listen to, others will repeat the old ones'. ${ }^{100}$

98 Bosch, 'Gender and the Personal in Political Biography', 14.

99 Bosch, 'Gender and the Personal in Political Biography', 14.

100 Bosch, 'Gender and the Personal in Political Biography', 32. 
This text is taken from Australian Journal of Biography and History: No. 5, 2021, published 2021 by ANU Press, The Australian National University, Canberra, Australia.

doi.org/10.22459/AJBH.05.2021.02 